Historic, archived document

Do not assume content reflects current scientific knowledge, policies, or practices. 
United States

Department

of Agriculture

Forest Service

Intermountaln

Research Station

Research Paper

INT-RP-476

Root Dipping of Conifer Seedlings Shows Little Benefit in the Northern July 1994

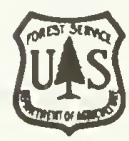
Rocky Mountains

John P. Sloan

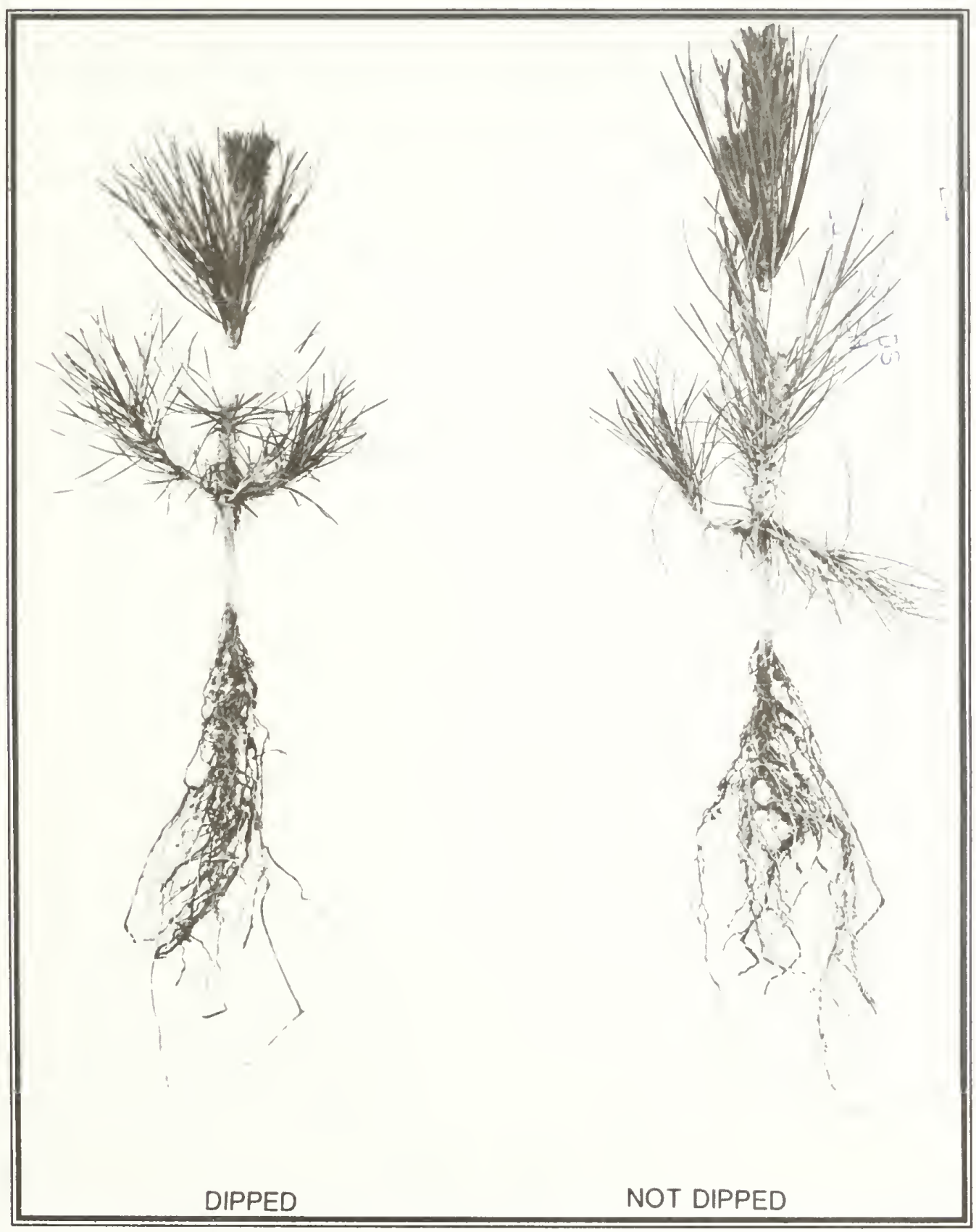




\section{The Author}

John P. Sloan is a Research Forester in the Ecology and Regeneration of Rocky Mountain Conifers Research Work Unit at Boise, ID. He received a B.A. degree in biology from Wartburg College and an M.S. degree in forest ecology from the University of Minnesota. He joined the Intermountain Research Station in 1984.

\section{Research Summary}

Several root dips (vermiculite, light vermiculite slurry, medium vermiculite slurry, thick vermiculite slurry, Terra Sorb ${ }^{\circledR}$, and Aquagel ${ }^{\circledR}$ ) were compared on seedlings of four conifer species: lodgepole pine (four experiments), ponderosa pine (three experiments), Douglas-fir (two experiments), and Engelmann spruce (one experiment). The studies took place in the growth chamber, in the greenhouse, and in the field. Potted seedling studies included forest soils with three different textures: basaltic loamy clay, granitic loamy sand, and limestone clay loam. We made a fourth soil from peat, vermiculite, and sandy loam.

The effects of root dipping varied with species, soil type, and the type of root dip. Under dry conditions, root dipping did not improve shoot growth, root growth, or survival. The thickest root dip treatments inhibited root growth. Lodgepole pine produced the best root growth. The peat-vermiculite-sandy loam soil was the most conducive to root growth. Seedlings on the basaltic soil showed the lowest plant water potential. More mycorrhizal activity took place on the granitic soil.

If conifer planting stock is handled properly in the Northern Rocky Mountains, avoiding exposure of roots to drying elements, root dipping is not necessary.

The cover photo shows ponderosa pine seedlings that were root dipped or were not root dipped before being planted in peat-vermiculite soil.

The use of trade or firm names in this publication is for reader information and does not imply endorsement by the U.S. Department of Agriculture of any product or service. 


\title{
Root Dipping of Conifer Seedlings Shows Little Benefit in the Northern Rocky Mountains
}

\author{
John P. Sloan
}

\section{Introduction}

Root dips coat the root systems of bareroot seedlings with some kind of water-holding or growthstimulating substance before planting. Foresters have experimented with root dips for many years and they have often been used when planting. Sloan (in press) describes four root dip categories and the various types of root dips that have been used on North American conifers: soil slurries, vermiculite or ground sphagnum moss, hydrophilic gels, and other materials, including organic substances, bioregulants, pesticides, and other chemicals.

Clay slurries and hydrophilic gels have been the most popular root dips. They made their way into reforestation as a means to protect seedlings during storage, to protect seedlings from exposure to drying conditions before planting, and to hold water in the root zone of newly planted seedlings. They have been found to be effective in protecting conifer seedlings against exposure to sun, wind, and other drying conditions before planting (Dierauf and Marler 1969, 1971; Owston and Stein 1972; Tabor and Davey 1966; Williston 1967), but were detrimental to seedlings during cold storage (Dierauf and Marler 1969; Mullin and Bunting 1979; Williston 1967). Sloan (in press) reviewed the published results of root-dip studies, finding few studies where root dipping improved the survival and growth of conifer seedlings that were protected against drying.

In the early 1970's the U.S. Department of Agriculture, Forest Service's Intermountain Region made root dipping in a vermiculite and water mixture a standard step when preparing bareroot seedlings for planting. Vermiculite absorbs and holds moisture that would otherwise drip off the root system or evaporate during drying conditions. The Targhee National Forest used a pump to keep the vermiculite suspended in water. The pump ground the vermiculite into a slurry that looked, felt, and acted much like clay slurry. Since then, various hydrophilic gels have been tried as root dips throughout the region.

Intermountain planting sites are noted for their hot, dry conditions during the summer months. Root dipping was supposed to help moderate the harsh conditions. This paper is a report of an investigation into the effect of root dipping in vermiculite, vermiculite slurry, or hydrophilic gels on the growth and survival of western conifer planting stock in the Intermountain West.

\section{Materials and Methods}

Tests took place in growth chambers, in a greenhouse, and under field conditions. All stock was 2-0 (2 years in the nursery bed, 0 years in the transplant bed) bareroot seedlings grown at Lucky Peak Nursery near Boise, ID: ponderosa pine (Pinus ponderosa Dougl. ex Laws.), lodgepole pine (Pinus contorta var. latifolia Engelm.), Douglas-fir (Pseudotsuga menziesii var. glauca [Beissn.] Franco), and Engelmann spruce (Picea engelmannii Parry ex Engelm.). For growth chamber and greenhouse tests, seedlings were hand lifted as soon as nursery conditions allowed and stored in plastic bags at $36^{\circ} \mathrm{F}$ for 7 days or less. For the field tests, seedlings were lifted and stored in Kraft Poly bags on the National Forest District where they were planted. All stock was dormant, with the exception of the Douglas-fir in the second greenhouse experiment. The poor root growth of that Douglas-fir stock indicated that the seedlings probably broke dormancy before they were lifted.

\section{Measurements}

For new root growth, long and short roots were treated differently. All new roots shorter than $1.5 \mathrm{~cm}$ were counted. Most roots in this category were shorter than $0.5 \mathrm{~cm}$. Roots longer than $1.5 \mathrm{~cm}$ were counted and measured to the nearest centimeter. The total length of all new roots was calculated by multiplying the number of short roots by $0.5 \mathrm{~cm}$ and adding the sum of all long roots. An index of mycorrhizal activity was estimated by counting the number of mycorrhizal root tips on the first $10 \mathrm{~cm}$ of the second lateral root from the root collar.

Shoot heights were measured from the ground line to the tip of the terminal bud, to the nearest centimeter. If there was no terminal bud, height was measured to the base of the needles nearest the shoot's tip. 
We measured plant water potential on the main stem of each seedling before dawn using a pressure bomb.

\section{Growth Chamber Tests}

We tested the effects of vermiculite slurry on lodgepole pine seedlings in growth chambers. All roots were trimmed to 8 inches. The composition of the slurry was a 12:10 ratio of number 4 grade agricultural vermiculite to water. The mixture was run through a pump to grind up the vermiculite and form a muddy suspension. Treated seedlings were dipped before being potted in 9 -inch pots. Control seedlings were not dipped. Pots were randomly arranged in three growth chambers. Conditions were set at 16 hours light period daily, with temperatures of $75^{\circ} \mathrm{F}$ during light and $60^{\circ} \mathrm{F}$ during dark. At the end of 1 month, the seedlings were carefully removed from the pots, soil was washed from their roots, and the light-colored new roots were counted and measured.

Growth Chamber Experiment 1-The objective of our first experiment in the growth chamber was to determine the effects of a vermiculite slurry root dip on lodgepole pine root and shoot growth. It lasted 31 days in February and March of 1984. The sample size was 30 seedlings: 15 dipped and 15 controls. The potting medium was a 1:1:1 mixture by volume of sandy loam soil, peat moss, and vermiculite. The pots were watered to saturation twice a week.

Growth Chamber Experiment 2-The objective of the second experiment was to determine the effects of the same root-dip substance on the shoot and root growth of lodgepole pine seedlings in four different soils. It lasted 30 days in March and April of 1985. The sample size was 48 seedlings. Six replications of eight seedlings were divided between three growth chambers, two replications in each chamber. Each replication consisted of a dipped and an undipped tree, planted in soils of four different origins: limestone forest soil, granitic forest soil, basaltic forest soil, and peat-vermiculite-sandy loam (see Growth Chamber Experiment 1). Pots were randomly arranged within the growth chamber for each replication. Pots were watered to saturation once each week.

\section{Greenhouse Tests}

Greenhouse temperatures were held between 60 and $80^{\circ} \mathrm{F}$ at Lucky Peak Nursery. All pots were watered to saturation once a week. As in the growth chamber experiments, the seedlings were carefully removed from their pots after 30 days, the soil was washed from their roots, and the new root growth was counted and measured. Other measurements included leader elongation, plant water potential at 30 days, and the number of mycorrhizal root tips per 10-cm sample of root.

Greenhouse Experiment 1-The objective of the first experiment was to determine the effects of the vermiculite slurry root dip on shoot and root growth of ponderosa pine and Douglas-fir seedlings. It was conducted in March and April of 1984. Fortyeight Douglas-fir and 48 ponderosa pine seedlings were trimmed to a root length of 8 inches and potted in 9 -inch pots. Eight blocks of 12 seedlings were grouped on the center bench of the greenhouse. Each block consisted of six ponderosa pine and six Douglas-fir seedlings, half of them root dipped and half undipped, planted in soils of three different origins: granitic forest soil, basaltic forest soil, and peat-vermiculite-sandy loam (see Growth Chamber Experiment 1). The rootdip material was the vermiculite slurry described in the growth chamber experiments. Pot arrangement within each block was random.

Greenhouse Experiment 2-The objective of the second experiment was to determine the effects of four different root-dip substances on shoot and root growth of four conifer species planted on three different soils. The experiment took place in March and April of 1985. We tested four conifer species: Douglas-fir, Engelmann spruce, lodgepole pine, and ponderosa pine. They were treated in one of five ways:

- Root dipped in a 12:10 (by volume) vermiculite and water mixture.

- Root dipped in a vermiculite slurry with a 6:10 vermiculite-to-water ratio.

- Root dipped in a vermiculite slurry with a 12:10 vermiculite-to-water ratio.

- Root dipped in a vermiculite slurry with a 18:10 vermiculite-to-water ratio.

- No root dip.

Vermiculite slurries were prepared in a blender. All of the seedlings were potted in half-gallon cardboard milk cartons. The potting soil was from three different parent materials: granitic forest soil, basaltic forest soil, and a mixture of peat moss, vermiculite, and sandy loam (see Growth Chamber Experiment 1). Seedlings from each of the root-dip treatments and a control were potted in each soil. Five treatments for each of three soils for each of four species made a total of 60 seedlings per block. Treatments were randomly arranged in eight blocks.

\section{Field Tests}

All seedlings were stored, handled, and prepared for planting according to Forest Service Intermountain Region Reforestation Guidelines (Dahlgreen 1976). Seedlings were divided into groups of about 20 , and the roots were submerged up to the root collars in a 
5-gal bucket of the appropriate root-dip mixture. The excess material was allowed to drip off the roots. Then the seedlings were placed on a piece of wet burlap and rolled into a jellyroll to protect the roots during acclimatization and planting. Jellyrolling is a process in which the seedlings are distributed with their roots on a piece of wet burlap. The burlap is rolled sideways like a carpet so that the shoots stick out the top and the roots are protected inside. Seedlings were acclimatized at 40 to $45{ }^{\circ} \mathrm{F}$ for 18 hours.

Seedlings were transported to the study sites in the morning just before planting. To prevent unnecessary exposure, each seedling went directly from the wet burlap of the planting bag into the planting hole. Each tree planter planted an equal number of all treatments.

Field Test 1 -The objective in the first field test was to determine the effects of three different root dips on survival and growth of lodgepole pine in a soil of basaltic origin. Ten blocks were placed in one continuous study plot on the Ashton Ranger District of the Targhee National Forest with a silt-loam soil of basaltic origin. Seedlings were planted on June 8, 1983. The site had a northeasterly aspect with less than a 10 percent slope at $5,900 \mathrm{ft}$ elevation. The habitat type was Douglas-fir/pine grass (Pseudotsuga menziesii/Calamagrostis rubescens) (Steele and others 1983).

Seedlings were stored in a snow cache at $32^{\circ} \mathrm{F}$ before planting. The site was prepared for planting using an SFI mechanical scalper. Each block consisted of four 12-tree rows. Each row contained one of the root-dip treatments: vermiculite; vermiculite slurry; Terra Sorb $^{\circledR}$, a commercially produced hydrophilic gel; or a control treatment in which seedlings were dipped in water. Treatment rows were randomly arranged in each block. After 35 days of growth, one tree from each row was excavated to measure new root growth. Six weeks after planting, the seedlings were released from grass competition by applying Roundup ${ }^{\circledR}$ herbicide in a 4 - by 4 -ft area around each tree.

Field Test 2-The objective of the second test was to determine the effects of three different root dips on survival and growth of ponderosa pine on a soil of granitic origin in the Boise National Forest. The treatments were similar to those in the first field test except that Aquagel ${ }^{\circledR}$, another commercially available hydrophilic gel, was tested instead of Terra Sorb ${ }^{\circledR}$. Planting stock was stored in a cooler at $34^{\circ} \mathrm{F}$ before planting on the Idaho City Ranger District in April 1988.

The habitat type was Douglas-fir/ninebark (Pseudotsuga menziesii/Physocarpus malvaceus) (Steele and others 1981). The study site straddled a draw. Three blocks, facing southwest, were placed on one side of the draw. Seven blocks faced east. Average slope was 35 percent; the elevation was 5,400 feet.
The trees were planted on 2- by 2 - $\mathrm{ft}$ hand scalps constructed just before the holes were augered. Four different treatment rows were randomly arranged in each block, as in the first field test. Forty-two days after planting, one tree from each row was excavated and its root growth was measured.

\section{Analysis}

Each experiment was set up in a randomized block design. Data were analyzed using analysis of variance tables at a 95 percent level of confidence. Differences between means were determined using Duncan's range test, again at a 95 percent level of confidence.

\section{Results}

We found that results differed with species, type of root dip, and soil texture. The results are summarized for growth chamber experiments, greenhouse experiments, and field studies.

\section{Growth Chamber Studies}

In early growth chamber studies we tested only lodgepole pine seedlings potted in a medium conducive to root growth. We looked at the effects of only one root-dip substance, vermiculite slurry. Under these conditions vermiculite slurry root-dip treatments had little effect on the mean length of the new roots, but it decreased the number of new roots longer than $1.5 \mathrm{~cm}$ by about one-half. That meant the total length of new roots per seedling was less. The mean number of new roots shorter than $1.5 \mathrm{~cm}$ and terminal shoot growth were similar for dipped and undipped seedlings (table 1).

In the next growth chamber experiment, we expanded the methods to include four different potting media. Because of limited growth chamber space, we again tested only lodgepole pine.

Seedlings potted in the sandy granitic soil produced shorter roots on average than the other soils. Total numbers of new roots were similar for all four soils. The vermiculite slurry root dip reduced the number of new roots shorter than $1.5 \mathrm{~cm}$, the total length of new long roots longer than $1.5 \mathrm{~cm}$, and the summed length of all new roots (table 2).

Neither soil nor root-dip treatments caused differences in plant water potential, number of mycorrhizal root tips, or shoot elongation ( $\alpha=0.05)$.

\section{Greenhouse Studies}

In the first greenhouse experiment, the vermiculite slurry root-dip treatment reduced the number of short roots and the total length of new roots. Vermiculite slurry was detrimental to the growth of long roots for 
Table 1-Root growth of lodgepole pine trees during a 31-day growth period (growth chamber experiment 1). Significance is indicated by N.S. (not significant) or * (significant at $\alpha=0.05$ )

\begin{tabular}{lcccccc}
\hline Treatment & Seedllngs & $\begin{array}{c}\text { Mean } \\
\text { length of } \\
\text { new roots } \\
>1.5 \mathrm{~cm}\end{array}$ & $\begin{array}{c}\text { Mean } \\
\text { number of } \\
\text { new roots } \\
>1.5 \mathrm{~cm}\end{array}$ & $\begin{array}{c}\text { Est. mean, } \\
\text { total length } \\
\text { of roots } \\
\mathbf{> 1 . 5} \mathbf{~ c m}\end{array}$ & $\begin{array}{c}\text { Mean } \\
\text { number of } \\
\text { new roots } \\
\mathbf{0 . 2} \text { to } \mathbf{1 . 5} \mathbf{~ c m}\end{array}$ & $\begin{array}{c}\text { Mean } \\
\text { leader } \\
\text { elongation }\end{array}$ \\
\hline Dipped & No. & $\mathrm{cm}$ & No. & $\mathrm{cm}$ & No. & $\mathrm{cm}$ \\
Not dipped & 15 & $4.5 \mathrm{~N} . \mathrm{S}$. & $37^{*}$ & $161^{*}$ & 97 N.S. & 8.7 N.S. \\
\hline
\end{tabular}

Table 2-Summary data from 48 lodgepole pine seedlings grown in the growth chamber for 30 days (growth chamber experiment 2). Seedlings were either root dipped in a vermiculite slurry or were not dipped before being potted in one of four 'soil types. Mean values in each group followed by the same letter or by no letter are not significantly different $(\alpha=0.05)$

\begin{tabular}{|c|c|c|c|c|c|c|c|c|c|}
\hline Treatment & Seodlings & $\begin{array}{l}\text { Leader } \\
\text { growth }\end{array}$ & $\begin{array}{c}\text { Plant } \\
\text { water } \\
\text { potential }\end{array}$ & $\begin{array}{c}\text { Roots } \\
>1.5 \mathrm{~cm} \\
\end{array}$ & $\begin{array}{c}\text { Total } \\
\text { length } \\
\text { of roots } \\
>1.5 \mathrm{~cm} \\
\end{array}$ & $\begin{array}{l}\text { Mean } \\
\text { length } \\
\text { of roots } \\
>1.5 \mathrm{~cm}\end{array}$ & $\begin{array}{c}\text { Total } \\
\text { length } \\
\text { of all } \\
\text { new roots }\end{array}$ & $\begin{array}{c}\text { Roots } \\
\leq 1.5 \mathrm{~cm}\end{array}$ & $\begin{array}{l}\text { Mycorrhizal } \\
\text { root tips per } \\
\text { 10-cm sample }\end{array}$ \\
\hline \multicolumn{9}{|l|}{ Soil type } & No. .... \\
\hline Basalt & 12 & 5.8 & -0.20 & 55 & $275 b$ & $5.3 \mathrm{~b}$ & 654 & 757 & 74 \\
\hline Granite & 12 & 5.7 & -0.19 & 42 & $172 \mathrm{a}$ & $4 a$ & 551 & 758 & 87 \\
\hline Limestone & 12 & 5.8 & -0.24 & 51 & $292 \mathrm{~b}$ & $5.9 \mathrm{~b}$ & 717 & 849 & 83 \\
\hline Peat-vermiculite & $\theta \quad 12$ & 6 & -0.24 & 62 & $385 \mathrm{c}$ & $6.2 \mathrm{~b}$ & 674 & 579 & 114 \\
\hline \multicolumn{10}{|l|}{ Root dip } \\
\hline Dipped & 24 & 5.4 & -0.25 & 48 & $251 \mathrm{a}$ & 5.2 & $549 a$ & $596 \mathrm{a}$ & 76 \\
\hline Not dipped & 24 & 6.1 & -0.19 & 57 & $311 \mathrm{~b}$ & 5.4 & $749 \mathrm{~b}$ & $876 \mathrm{~b}$ & 102 \\
\hline Overall mean & 48 & 5.8 & -0.22 & 53 & 281 & 5.3 & 649 & 736 & 89 \\
\hline
\end{tabular}

ponderosa pine but did not affect Douglas-fir (fig. 1). Dipped seedlings bore more mycorrhizal root tips than nondipped seedlings, except on granitic soil where the result was just the opposite (fig. 2). The vermiculite slurry had no effect on plant water potential (table 3 ).

Root growth was better for ponderosa pine than for Douglas-fir seedlings on the peat-vermiculite-sandy loam soil. Root growth differed little between the species on the basaltic and granitic soils (fig. 3). Although the average long root length was the same for both species, ponderosa pine had a greater total root length because it had more long roots than Douglas-fir. Ponderosa pine also produced more mycorrhizal root tips. The number of roots shorter than $1.5 \mathrm{~cm}$ differed little between species. Ponderosa pine showed greater leader growth and higher plant water potential than Douglas-fir seedlings (table 3).

More new roots (longer than $1.5 \mathrm{~cm}$ ) were produced in the peat-vermiculite-sandy loam soil (table 3). Figures 3 and 4 show that peat-vermiculite-sandy loam soil was much better for pine root growth, but did not greatly improve Douglas-fir root growth. The granitic

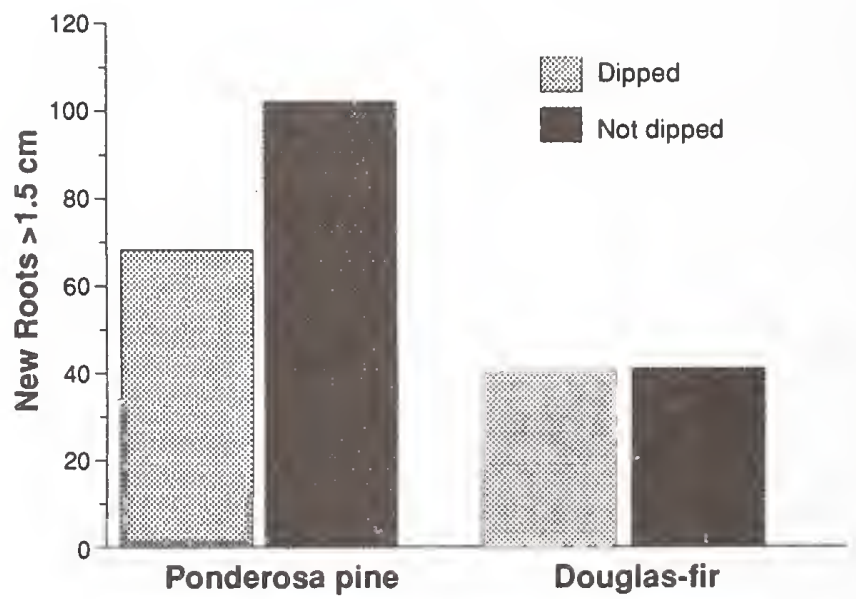

Figure 1-Average number of roots greater than $1.5 \mathrm{~cm}$ from 96 ponderosa pine and Douglas-fir seedlings grown in the greenhouse for 30 days (greenhouse experiment 1). Seedlings were root dipped in a vermiculite slurry or were not dipped before being potted in one of three soils. 


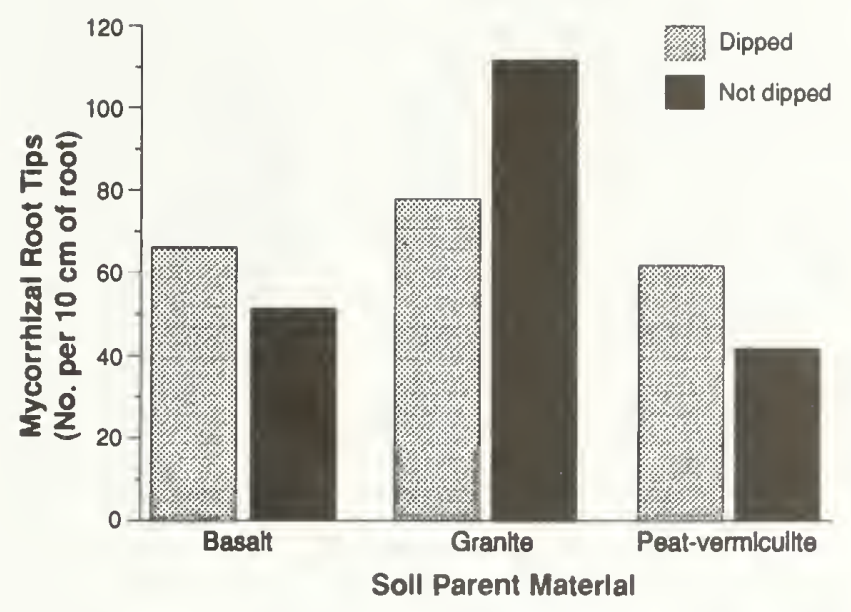

Figure 2-Average number of mycorrhizal root tips per $10-\mathrm{cm}$ sample or roots from 96 ponderosa pine and Douglas-fir seedlings grown in the greenhouse for 30 days (Greenhouse experiment 1). Seedlings were root dipped in a vermiculite slurry or were not dipped before being potted in one of three soils.

soil supported the shortest mean root length and the most short roots. Plant water potential was lowest on the basaltic soil and was highest on the peatvermiculite-sandy loam soil. The granitic soil was more favorable for mycorrhizal root tips, but the soil type influenced leader growth very little (table 3 ).

The second greenhouse experiment showed no conclusive difference in root growth between nondipped

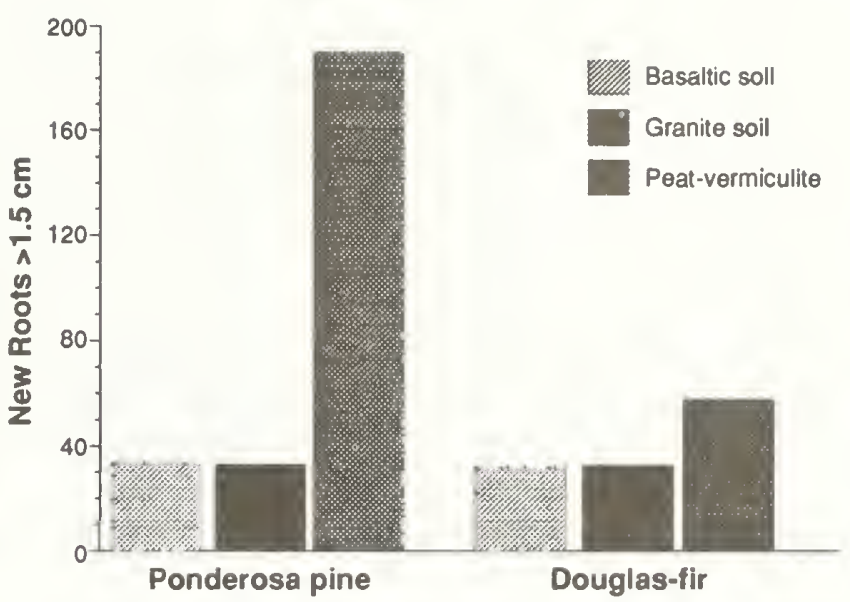

Figure 3-Average number of roots longer than $1.5 \mathrm{~cm}$ from 96 ponderosa pine and Douglas-fir seedlings grown in the greenhouse for 30 days (greenhouse experiment 1). Seedlings were root dipped in a vermiculite slurry or were not dipped before being potted in one of three soils.

seedlings, vermiculite, and the weak vermiculite slurry (table 4). However, figure 5 shows that root growth fell as seedlings were dipped in progressively thicker slurry. Likewise, nondipped seedlings produced more mycorrhizal root tips than the $2 x$ vermiculite slurry (table 4). The thicker vermiculite slurry treatments also caused lower plant water potential and poorer leader growth.

Table 3-Summary data from 96 ponderosa pine and Douglas-fir seedlings grown in the greenhouse for 30 days (greenhouse experiment 1). Seedlings were root dipped in a vermiculite slurry or were not dipped before being potted in one of three soil types. Mean values in each group followed by the same letter or by no letter are not significantly different $(\alpha=0.05)$

\begin{tabular}{|c|c|c|c|c|c|c|c|c|c|}
\hline Treatment & Seedlings & $\begin{array}{l}\text { Leader' } \\
\text { growth }\end{array}$ & $\begin{array}{c}\text { Plant } \\
\text { water } \\
\text { potential }\end{array}$ & $\begin{array}{l}\text { Roots }{ }^{2,3} \\
>1.5 \mathrm{~cm} \\
\end{array}$ & $\begin{array}{c}\text { Total } \\
\text { length } \\
\text { of roots } \\
>1.5 \mathrm{~cm} \\
\end{array}$ & $\begin{array}{c}\text { Mean } \\
\text { length } \\
\text { of roots } \\
>1.5 \mathrm{~cm} \\
\end{array}$ & $\begin{array}{c}\text { Total }{ }^{2} \\
\text { length } \\
\text { of all } \\
\text { new roots }\end{array}$ & $\begin{array}{l}\text { Roots } \\
\leq 1.5 \mathrm{~cm} \\
\end{array}$ & $\begin{array}{l}\text { Mycorrhlzal' } \\
\text { root tips per } \\
10-c m \text { sample }\end{array}$ \\
\hline Species & No. & $\mathrm{cm}$ & $M P a$ & No. & \multicolumn{3}{|c|}{$\ldots \ldots \ldots c m \ldots \ldots$} & \multicolumn{2}{|c|}{ 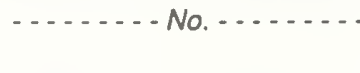 } \\
\hline Ponderosa pine & 48 & $6.2 \mathrm{a}$ & $-0.34 a$ & $84 a$ & $361 \mathrm{a}$ & 3.6 & $720 \mathrm{a}$ & 696 & $79 \mathrm{a}$ \\
\hline Douglas-fir & 48 & $5 b$ & $-1.61 b$ & $39 \mathrm{~b}$ & $147 \mathrm{~b}$ & 3.6 & $443 \mathrm{~b}$ & 593 & $56 \mathrm{~b}$ \\
\hline \multicolumn{10}{|l|}{ Soil type } \\
\hline Basaltic soil & 32 & 5.7 & $-1.04 \mathrm{a}$ & $31 \mathrm{a}$ & $107 \mathrm{a}$ & $3.5 b$ & $374 \mathrm{a}$ & $534 a$ & 59 a \\
\hline Granitic soil & 32 & 5.6 & $-0.97 b$ & 32 a & $89 \mathrm{a}$ & $2.8 \mathrm{a}$ & $470 \mathrm{~b}$ & $761 \mathrm{~b}$ & $94 \mathrm{~b}$ \\
\hline Peat-vermiculite & 32 & 5.6 & $-0.91 b$ & $123 \mathrm{~b}$ & $567 \mathrm{~b}$ & $4.5 \mathrm{c}$ & $902 \mathrm{c}$ & $639 a b$ & 51 a \\
\hline \multicolumn{10}{|l|}{ Root dip } \\
\hline Dipped & 48 & 5.7 & -0.96 & $53 a$ & $217 a$ & 3.6 & $490 \mathrm{a}$ & $544 a$ & 68 \\
\hline Not dipped & 48 & 5.5 & -0.99 & $71 b$ & $291 b$ & 3.6 & $674 b$ & $745 b$ & 67 \\
\hline Overall mean & 96 & 5.6 & -0.97 & 62 & 254 & 3.6 & 582 & 644 & 68 \\
\hline
\end{tabular}

\footnotetext{
'Analysis of variance showed a likely interaction between soil type and root-dip treatment.

${ }^{2}$ Analysis of variance showed a likely interaction between species and soil types.

${ }^{3}$ Analysis of variance showed a likely interaction between species and root-dip treatment.
} 


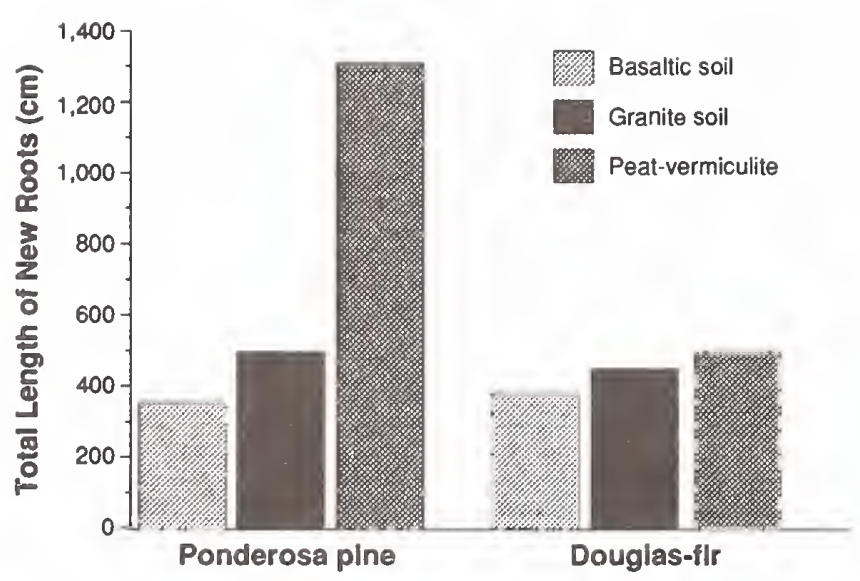

Figure 4-Average total length of roots longer than $1.5 \mathrm{~cm}$ from 96 ponderosa pine and Douglas-fir seedlings grown in the greenhouse for 30 days (greenhouse experiment 1). Seedlings were root dipped in a vermiculite slurry or were not dipped before being potted in one of three soils.

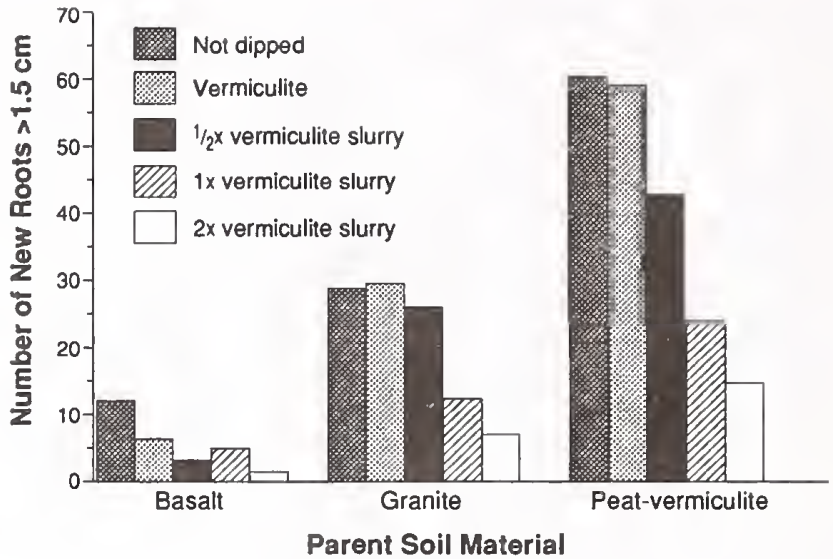

Figure 5-Average number of roots longer than $1.5 \mathrm{~cm}$ from 300 lodgepole pine, ponderosa pine, Douglas-fir, and Engelmann spruce seedlings grown in the greenhouse for 30 days (greenhouse experiment 2). Seedlings were dipped in one of four root dips: vermiculite, $1 / 2 x$ vermiculite slurry, $1 x$ vermiculite slurry, $2 x$ vermiculite slurry, or were not dipped before being potted in one of three soils: basaltic, granitic, or peat-vermiculite-sandy loam.

Table 4-Summary of data from 300 seedlings grown in the greenhouse for 30 days (greenhouse experiment 2). Four species were treated with one of five root dips before being potted in one of three soil types. Mean values in each group followed by the same letter are not significantly different $(\alpha=0.05)$

\begin{tabular}{|c|c|c|c|c|c|c|c|}
\hline Treatment & Seedlings & $\begin{array}{l}\text { Leader } \\
\text { growth }\end{array}$ & $\begin{array}{c}\text { Plant } \\
\text { water } \\
\text { potential }\end{array}$ & $\begin{array}{l}\text { Roots }{ }^{1,2} \\
>1.5 \mathrm{~cm}\end{array}$ & $\begin{array}{l}\text { Length }{ }^{1,2} \\
\text { of roots } \\
>1.5 \mathrm{~cm}\end{array}$ & $\begin{array}{l}\text { Roots }^{1} \\
\leq 1.5 \mathrm{~cm}\end{array}$ & $\begin{array}{l}\text { Mycorrhrizal } \\
\text { root tips per } \\
10-\mathrm{cm} \text { sample }\end{array}$ \\
\hline Species & No. & $\mathrm{cm}$ & $\mathrm{MPa}$ & No. & $\mathrm{cm}$ & \multicolumn{2}{|c|}{ 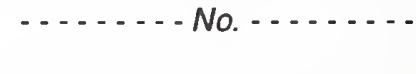 } \\
\hline Lodgepole pine & 75 & $9.8 \mathrm{c}$ & $-0.75 a$ & $43 c$ & $222 d$ & $318 \mathrm{c}$ & $51 \mathrm{c}$ \\
\hline Ponderosa pine & 75 & $6.7 \mathrm{~b}$ & $-0.77 a$ & $22 \mathrm{~b}$ & $97 \mathrm{c}$ & $176 \mathrm{~b}$ & $51 \mathrm{c}$ \\
\hline Douglas-fir & 75 & $2.2 \mathrm{a}$ & $-1.34 b$ & $4 a$ & $14 \mathrm{a}$ & $40 a$ & $6 a$ \\
\hline Engelmann spruce & 75 & $1.9 \mathrm{a}$ & $-0.81 a$ & $18 b$ & $56 \mathrm{~b}$ & $264 c$ & $32 \mathrm{~b}$ \\
\hline \multicolumn{8}{|l|}{ Soil type } \\
\hline Basalt & 100 & $4.6 \mathrm{a}$ & $-1.02 b$ & $6 a$ & $17 a$ & $123 a$ & 25 a \\
\hline Granite & 100 & $5.4 b$ & $-0.90 \mathrm{a}$ & $21 \mathrm{~b}$ & $79 \mathrm{~b}$ & $221 \mathrm{~b}$ & $44 \mathrm{~b}$ \\
\hline Peat-vermiculite & 100 & $5.5 \mathrm{~b}$ & $-0.84 a$ & $40 \mathrm{c}$ & $195 \mathrm{c}$ & $254 \mathrm{~b}$ & $34 a b$ \\
\hline \multicolumn{8}{|l|}{ Root dip } \\
\hline Not dipped & 60 & $5.7 \mathrm{c}$ & $-0.83 a$ & $34 \mathrm{c}$ & $144 \mathrm{~b}$ & $274 c$ & $44 \mathrm{~b}$ \\
\hline Vermiculite & 60 & $5.2 \mathrm{abc}$ & $-0.92 a b$ & 32 bc & $136 \mathrm{~b}$ & 239 bc & $38 a b$ \\
\hline $1 / 2 \times$ slurry & 60 & $5.4 \mathrm{bc}$ & $-0.89 a b$ & $24 \mathrm{~b}$ & $105 \mathrm{~b}$ & $205 a b c$ & $36 a b$ \\
\hline $1 \mathrm{x}$ slurry & 60 & $4.7 \mathrm{a}$ & $-1.01 b$ & $14 \mathrm{a}$ & $57 a$ & $158 a b$ & $34 a b$ \\
\hline $2 x$ slurry & 60 & $4.8 \mathrm{ab}$ & $-0.95 a b$ & $7 a$ & $43 a$ & $119 a$ & $22 \mathrm{a}$ \\
\hline Overall mean & 300 & 5.2 & -0.92 & 22 & 97 & 199 & 35 \\
\hline
\end{tabular}

'Analysis of variance showed a likely interaction between species and soil type.

${ }^{2}$ Analysis of variance showed a likely interaction between soil type and root-dip treatment. 
Lodgepole pine grew more long roots and had a greater total length of long roots than the other species (table 4). Whether ponderosa pine or Engelmann spruce was second best depended on the soil (fig. 6). Ponderosa pine roots grew best in the peat-vermiculitesandy loam soil, while Engelmann spruce showed more root growth than ponderosa pine in the basaltic and granitic soils. Douglas-fir produced the least long root growth (table 4).

Lodgepole pine grew the most short roots in the peat-vermiculite-sandy loam soil, but Engelmann spruce grew just as many short roots in the basaltic and granitic soils. Ponderosa pine had as many short roots as Engelmann spruce in the peat-vermiculitesandy loam soil (fig. 7). Douglas-fir produced the fewest short roots in this test. The two pine species exhibited the best mycorrhizal associations. Engelmann spruce was next best; Douglas-fir had only a small number of mycorrhizal root tips. Douglas-fir had a lower plant water potential than the other species (table 4).

Overall, root growth was best on the peat-vermiculitesandy loam soil, but the relationship is not quite so simple. Engelmann spruce grew more roots in the granitic soil than in the other two soils (figs. 6 and 7). Seedlings growing in the basaltic soil produced the least root growth, the least shoot growth, and lowest plant water potential. The granitic soil was more conducive to mycorrhizal associations than the basaltic (table 4).

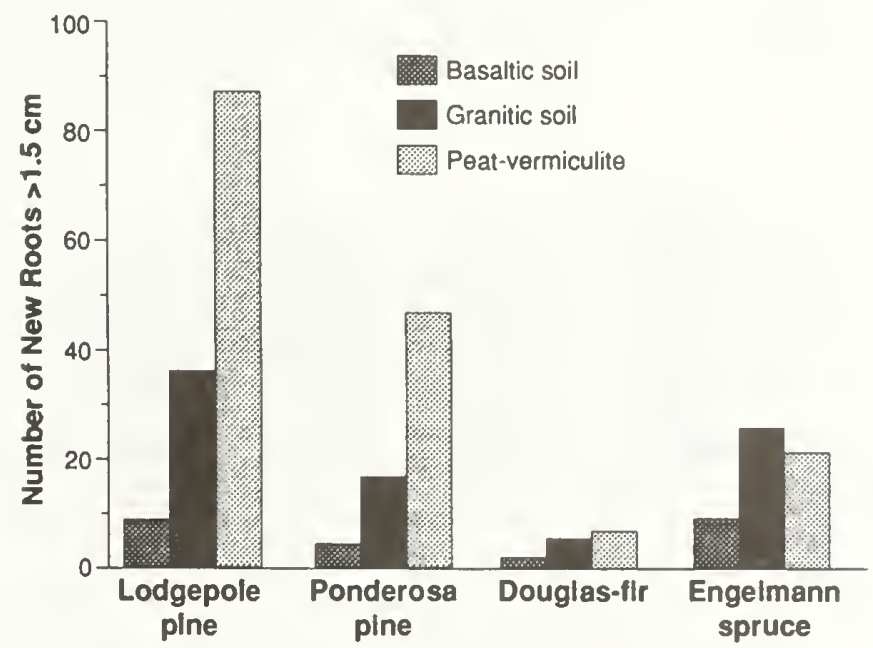

Figure 6-Average number of roots longer than $1.5 \mathrm{~cm}$ from 300 lodgepole pine, ponderosa pine, Douglas-fir, and Engelmann spruce seedlings grown in the greenhouse for 30 days (greenhouse experiment 2). Seedlings were root dipped in one of four materials or not dipped and potted in one of three soils: basaltic, granitic, or peatvermiculite-sandy loam.

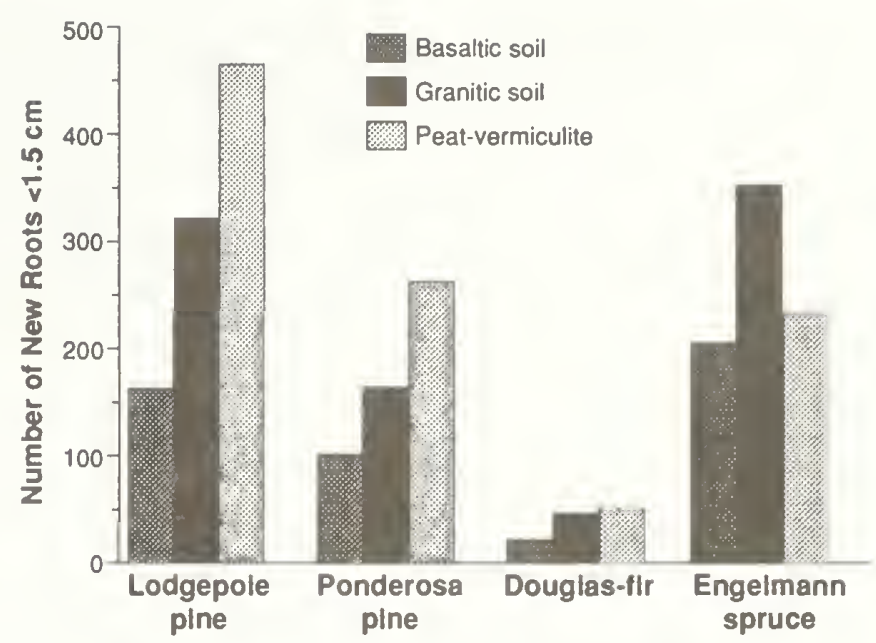

Figure 7-Average number of roots shorter than $1.5 \mathrm{~cm}$ from 300 lodgepole pine, ponderosa pine, Douglas-fir, and Engelmann spruce seedlings grown in the greenhouse for 30 days (greenhouse experiment 2). Seedlings were root dipped in one of four materials or were not dipped before being potted in one of three soils: basaltic, granitic, or peat-vermiculite-sandy loam.

\section{Field Studies}

The first field test showed no significant difference in lodgepole pine root growth after 30 days because of the large variability and small sample of trees (table 5). Survival was generally poor because of pocket gopher activity, but the seedlings dipped in vermiculite had a little higher survival. Most of the mortality came during the first winter and second growing season (fig. 8). Mean height figures were also reduced because gophers sometimes clipped seedlings off above ground but did not kill them. Still, the mean heights for all treatments tripled in 3 years (fig. 9). There was no significant difference between treatments after 3 years $(\alpha=0.05)$.

In the second field test, seedlings root dipped in the vermiculite slurry produced more new roots than those in the vermiculite treatment and those that received no treatment (table 6). The Aquage ${ }^{\circledR}$ seedlings were intermediate. There was little difference between treatments in the mean length of the new roots longer than $1.5 \mathrm{~cm}$.

Third-year mean seedling height and survival showed little difference between the treatments (table 6). Seedling growth was fair during the first growing season, very poor during the second, and poor in the third (fig. 10). The poor growth was due to drought conditions on the site during July and August of the first two growing seasons. Survival dropped considerably between the first and second 
Table 5-Average lodgepole pine root growth after 30 days and average seedling heights and survival after 3 years on the Targhe日 National Forest. Treatment means showed no significant differences $(\alpha=0.05)$

\begin{tabular}{|c|c|c|c|c|c|c|}
\hline \multirow[b]{3}{*}{ Treatment } & \multicolumn{4}{|c|}{ New root growth } & & \\
\hline & \multirow{2}{*}{$\begin{array}{l}\text { No. of roots } \\
0.2-1.5 \mathrm{~cm} / \text { tree }\end{array}$} & \multicolumn{2}{|c|}{ Roots $>1.5 \mathrm{~cm}$} & \multirow{2}{*}{$\begin{array}{c}\text { No. mycorrhlzal } \\
\text { root tips } / 10-\mathrm{cm} \\
\text { sample }\end{array}$} & \multicolumn{2}{|c|}{ Third year } \\
\hline & & No./tree & Avg length & & Height & Survlval \\
\hline & $\ldots \ldots . . . . . . . N$ & $\ldots . .$. & $\mathrm{cm}$ & No. & $\mathrm{cm}$ & Percent \\
\hline Vermiculite & 51 & 7 & 2.1 & 15 & 37.6 & 70 \\
\hline Vermiculite slurry & 26 & 9 & 2.7 & 17 & 33.9 & 60 \\
\hline Terra Sorb ${ }^{\otimes}$ & 67 & 11 & 2.5 & 19 & 34.0 & 62 \\
\hline Not dipped & 54 & 15 & 2.5 & 18 & 33.6 & 61 \\
\hline
\end{tabular}

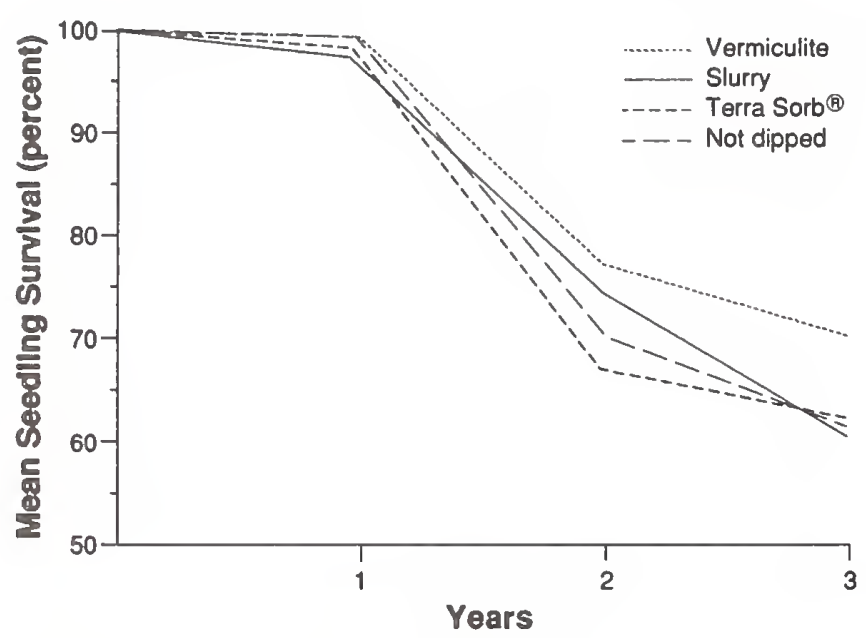

Flgure 8-Average lodgepole pine seedling survival from 480 seedlings after the first three growing seasons on the Targhee National Forest (field experiment 2). Seedlings were root dipped in vermiculite, vermiculite slurry, or Terra Sorb ${ }^{\circledR}$, or they were not dipped.

growing seasons (fig. 11). However, spring measurements indicated most of that mortality took place during the first winter, probably from the stresses of the preceding summer. Survival was very good between the second and third years.

\section{Discussion}

We conducted two experiments in the growth chamber, two in the greenhouse, and two in the field. In these tests, the effects of root dipping depended on root-dip treatment, soil parent material, and conifer seedling species. We tightly controlled environments in the growth chamber experiments. The greenhouse experiments allowed us to trade some of the control for an increased sample size. In the field experiments we examined whether our results applied in a practical sense. The data showed a great deal of variability. Nevertheless, I found good consistency in the results between most of the greenhouse and growth chamber experiments and field tests.

The root-dip treatments we studied did not increase seedling root growth. None of the treatments had much effect on the mean length of new roots or mycorrhizae production. The number of long roots, the total length of long roots, and the number of short roots was the same for undipped seedlings as for dipped seedlings or was even better. Most of the time, vermiculite and hydrophilic gels did not reduce root growth. However, the thicker the vermiculite slurry treatment, the more detrimental it was to root growth.

The exception was in the second field experiment where the vermiculite slurry increased seedling root growth over the undipped seedlings. This may be because the site conditions were moister during the

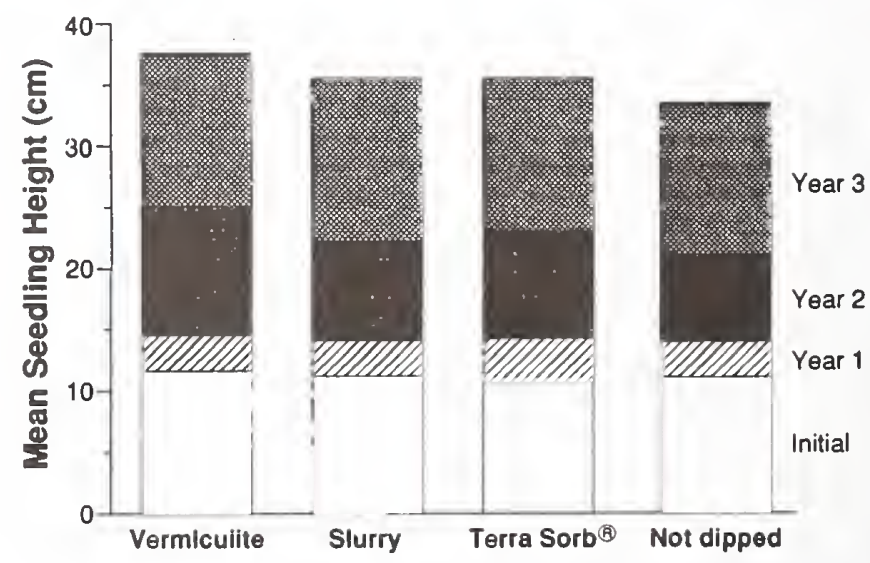

Flgure 9-Average lodgepole pine seedling heights from 480 seedlings after the first three growing seasons on the Targhee National Forest (field experiment 1). Seedlings were root dipped in vermiculite, vermiculite slurry, or Terra Sorb ${ }^{\oplus}$, or they were not dipped. 
Table 6-Average ponderosa pine root growth after 30 days and average seedling heights and survival after 3 years on the Targhee National Forest. Means in each column followed by the same letter or by no letters are not statistically different $(\alpha=0.05)$

\begin{tabular}{|c|c|c|c|c|c|c|c|}
\hline \multirow[b]{3}{*}{ Treatment } & \multicolumn{5}{|c|}{ Third year root growth } & \multirow{2}{*}{\multicolumn{2}{|c|}{ Third year }} \\
\hline & \multirow{2}{*}{$\begin{array}{l}\text { Roots } \\
<0.5 \mathrm{~cm} \\
\end{array}$} & \multirow{2}{*}{$\begin{array}{c}\text { Roots } \\
0.5-2.0 \mathrm{~cm}\end{array}$} & \multirow{2}{*}{$\begin{array}{l}\text { Roots } \\
>2.0 \mathrm{~cm}\end{array}$} & \multirow[b]{2}{*}{ Total length } & \multirow[b]{2}{*}{ Avg. length } & & \\
\hline & & & & & & Helght & Survival \\
\hline & $\ldots .$. & - - No. - - - & $\ldots$ & $\ldots \ldots$ & $-\mathrm{cm}$ - & $\cdots$ & Percent \\
\hline Vermiculite & 357 & 48 a & $17.8 \mathrm{a}$ & $62 \mathrm{a}$ & 2.8 & 34.6 & 80.2 \\
\hline Vermiculite slurry & 540 & $104 b$ & $33.2 \mathrm{~b}$ & $130 \mathrm{~b}$ & 3.8 & 36.5 & 81.0 \\
\hline Aquagel $^{\circledR}$ & 349 & 58 a & $21.8 \mathrm{ab}$ & $85 a b$ & 3.5 & 34.6 & 74.6 \\
\hline Not dipped & 321 & $41 a$ & $15.7 \mathrm{a}$ & 58 a & 3.5 & 36.4 & 76.8 \\
\hline
\end{tabular}

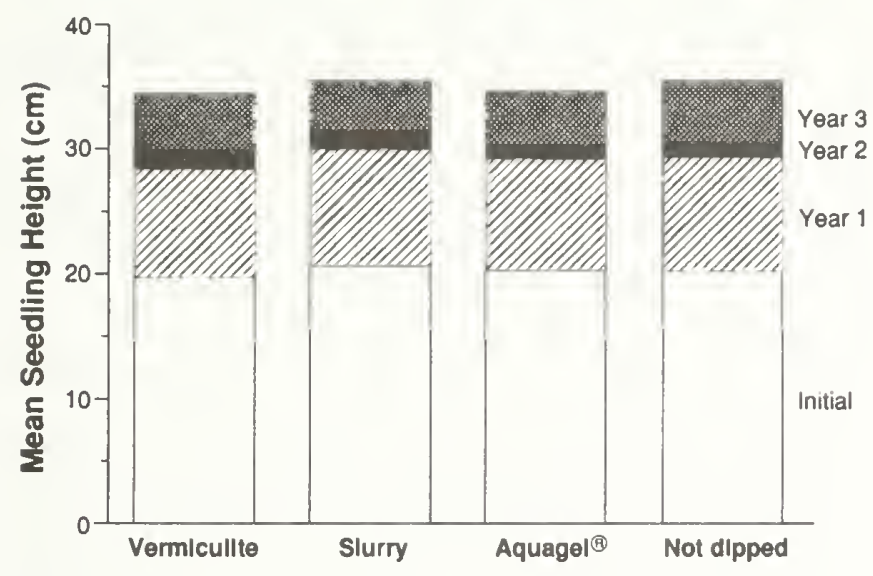

Figure 10-Average ponderosa pine seedling heights from 480 seedlings after the first three growing seasons on the Boise National Forest (field experiment 2). Seedlings were root dipped in vermiculite, vermiculite slurry, or Aquage $\mathrm{I}^{\circledR}$, or they were not dipped.

first month after planting than in the greenhouse experiments, growth chamber experiments, and the other field test. Precipitation for April and May 1988 was 115 percent of normal at the Idaho City, ID, weather station. Under favorably moist conditions, the vermiculite slurry may be beneficial, perhaps because it provides a greater cation exchange capacity than the surrounding sandy loam soil.

Root growth varied with species and soil type. Lodgepole pine grew the most roots on average. However, on granitic or basaltic soils Engelmann spruce root growth was just as good. To further rank species, ponderosa pine had the second-best root growth on the peat-vermiculite-sandy loam soil. Douglas-fir produced the fewest roots on all of the soils. In the second greenhouse experiment the Douglas-fir root growth was less than in the first because the seedlings were lifted too late in the spring.
Table 5 shows that in every category of root growth measurement, the undipped seedlings produced as many or more new roots as root-dipped seedlings. However, the situation is not as simple as it may seem. Although the undipped seedlings produced more long roots, figure 1 shows that only ponderosa pine roots produced a difference; there was little difference in the number of Douglas-fir roots.

The peat-vermiculite-sandy loam soil, with its higher organic matter content, held more water and was more conducive to root growth. The granitic soil with little organic content and large pore spaces held the least water. But the water was not held tightly and most of it was available for uptake by roots. The basaltic soil, with its high clay content, held more water than the granitic soil, but little water was available to roots when the soil became dry and brick hard. These

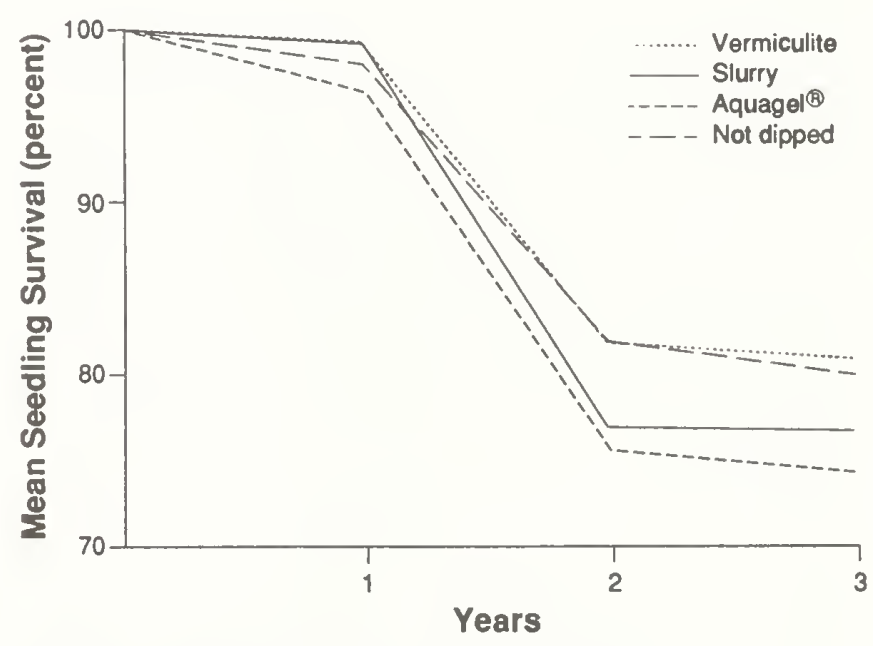

Figure 11-Average ponderosa pine seedling survival heights from 480 seedlings after the first three growing seasons on the Boise National Forest (field experiment 2). Seedlings were root dipped in vermiculite, vermiculite slurry, or Aquage ${ }^{\otimes}$, or they were not dipped. 
observations were supported by plant water potential measurements in the greenhouse experiments. One notable exception: the Engelmann spruce seedlings grew more new roots in the granitic soil than in the peat-vermiculite-sandy loam soil.

Root dipping did not increase plant water potential in any of the experiments. This finding is important because the reason for root dipping seedlings on harsh planting sites in the western United States is to hold more available water in the seedling root zone. In fact, the amount of water held by a root dip is insignificant in the overall context of planting site water dynamics, especially in dry habitat types. Magnussen (1986) found that a hydrophilic gel increased the survival of white spruce for the first 2 weeks of drought, but for no longer. Similarly, Tung and others (1986) saw that hydrophilic gel delayed the first-year mortality of Douglas-fir but did not affect season-end survival and growth.

What happens after the root dip particles dry out? It is doubtful that they can pull water away from the tree root system. If so, we would have seen more detrimental effects in our experiments. Instead, they contract and harden. The thick slurries form a hard coating. The hydrophilic gel crystals shrink to leave small air pockets.

Under moist soil conditions, some of the root dips may help early seedling growth because of their higher cation exchange capacity relative to the surrounding soil. This would hold available nutrients in the root zone. However, nutritional benefits to planted seedlings appear to be small; the root dip is dwarfed by the overall conditions on the planting site. Also this benefit would be short lived due to the expansion of the root system.

The granitic soil was best for mycorrhizal growth, possibly because it was less fertile. Mycorrhizal root tip production differed little between the basaltic and peat-vermiculite-sandy loam soils. We did not test for mycorrhizal inoculum on the seedlings or in the soils, nor did we inoculate the seedlings in any of the experiments. However, the forest soils almost certainly contained inoculum, and the growth of mycorrhizae even in the peat-vermiculite-sandy loam soil indicates that the seedlings brought a mycorrhizal source from the nursery.

Root dip had two observable effects on seedling top growth. Seedlings dipped in the two thickest vermiculite slurries had less shoot elongation than undipped seedlings because of higher water stress. After three growing seasons the lodgepole pine seedlings dipped in vermiculite before being planted in the basaltic soil were slightly larger on average than undipped seedlings, although this finding was not conclusive. Recorded precipitation at nearby Ashton, ID, was 51 percent above average, 28 percent above average, and near average for the 3 years after planting. The above-average precipitation may explain why the root-dipped seedlings performed well.

Although precipitation was well above normal, survival dropped during the second and third years of the first field experiment. Pocket gophers were responsible for much of the mortality. Precipitation was below normal during the three growing seasons after seedlings were planted in the second field experiment. However, the results were the same: no significant difference in survival due to any root-dip treatment.

Our results agree with those of Ryker (1981). He reported that vermiculite and Vitera ${ }^{\circledR}$ root dips did not increase survival and growth of Douglas-fir, ponderosa pine, or lodgepole pine. Tung and others (1986) found that Terra Sorb ${ }^{\circledR}$ did not affect Douglas-fir seedling survival and growth. Likewise, Tuskan and Ellis (1991) found a Waterlock ${ }^{\circledR}$ root dip did not influence ponderosa pine seedling survival and growth. Waterlock $^{\circledR}$ and Vitera ${ }^{\circledR}$ are hydrophilic gels much like Terra Sorb $^{\circledR}$ and Aquagel ${ }^{\circledR}$, the products we tested.

Likewise, Mullin and Hutchison (1977) found that Agricol ${ }^{\circledR}$ root dip did not increase survival and growth of jack pine and black spruce. The same was true for slash pine seedlings dipped in Terra Sorb ${ }^{\circledR}$ (Kroll and others 1985) and red pine dipped in Waterlock ${ }^{\circledR}$ (Magnussen 1986). Echols and others (1990) found that loblolly and shortleaf pines dipped in Terra Sorb ${ }^{\circledR}$ survived better than undipped seedlings on a moderate site but not on a harsh one.

Our results do not fit with those of Kroll and others (1985) where Terra Sorb ${ }^{\circledR}$ root dip increased survival of loblolly pine on a droughty site.

Johnson (1984) demonstrated that gel-forming polyacrylamides stored large amounts of water in sandy soils. However, when this material is used as a root dip, the small amount of gel adhering to the roots has to give up its moisture not only to the seedling roots, but also to the soil around it to reach equilibrium. With so much soil to draw off water, in a dry environment the small amount of water held in the hydrophilic gels can soon disappear.

The moisture release curve for vermiculite slurry is similar to that of a clay soil. Both can hold a great deal of water, which is why they have been used as root dips. However, under dry conditions, the fine particles hold water very tightly. Although work has not been done on western conifers, the literature shows that clay slurry root dips at best do not improve seedling survival and growth (Dierauf and Marler 1969; Mullin and Bunting 1979; Sloan, in press; Williston 1967). The reason some of these studies showed clay slurries to be detrimental and the reason the thicker vermiculite slurry treatments curtailed root growth in our study, may be due to inadequate aeration. 
Thick slurries can prevent oxygen from penetrating to the root system in heavy soils.

Most of our experiments dealt with dry soil conditions, very similar to typical planting sites in the Intermountain West. Under these conditions, rootdip treatments did not increase root growth, shoot growth, or survival of lodgepole pine, ponderosa pine, Douglas-fir, or Engelmann spruce. In most cases these root dips were not detrimental, but for potted trees, the thicker the vermiculite slurry, the poorer the seedling root growth. This may translate into reduced survival and growth under field conditions.

Other work has shown that root dips reduce harmful effects of seedling root exposure prior to planting (Dierauf and Marler 1969, 1971; Owston and Stein 1972; Tabor and Davey 1966; Williston 1967). Even so, when nursery stock is protected during lifting, handling, storage, and planting, there is no reason to bother with root dipping. It is more important to start with vigorous planting stock, protect the seedlings from exposure, and maintain their vigor until they are properly planted.

\section{Summary}

The root dips did not improve seedling root or shoot growth under dry conditions. In potted seedling experiments the undipped seedlings produced as many or more roots than the root-dipped seedlings. The thicker the vermiculite slurry treatment, the less roots grew.

Seedling growth and survival were not significantly affected by root-dip treatment. Overall, the root-dip treatments did not change plant water potential or the seedlings' ability to form mycorrhizal associations.

Lodgepole pine seedlings grew more new roots than seedlings of other species. Lodgepole pine performed best on the peat-vermiculite-sandy loam soil. Engelmann spruce produced as many new roots as lodgepole on the two forest soils and grew better than the other species on granitic soil. Ponderosa pine also grew well on the peat-vermiculite-sandy loam soil. Douglas-fir root growth was the poorest of all species on all soils.

The peat-vermiculite-sandy loam was the soil most conducive to seedling root growth for all species except Engelmann spruce. More mycorrhizal root tips were produced on the granitic soil; the least were produced on the basaltic soil. Seedlings on the basaltic soils also showed the lowest plant water potential.

Root dipping has been used in the Intermountain West, where soils and planting sites often become very dry during summer. One purpose of root dips is to protect seedlings against exposure or anything else that could go wrong before planting. Instead, managers should make every effort to prevent seedlings from being exposed to sun and wind, to maintain the vigor of nursery stock before planting, and to properly plant each seedling. The second purpose of root dips is to protect seedlings against the normally dry summer climate that sometimes turns droughty. It appears that even under these conditions the root dip treatments do not help the seedlings and in some cases may harm them.

\section{References}

Dahlgreen, Allen K. 1976. Care of forest tree seedlings from nursery to planting hole. In: Proceedings: tree planting in the Inland Northwest; 1976 February 17-19; Pullman, WA. Ogden, UT: U.S. Department of Agriculture, Forest Service, Intermountain Region: 204-238.

Dierauf, T. A.; Marler, R. L. 1969. Clay dipped vs. bare rooted seedling survival. Tree Planters' Notes. 20(2): 5-8.

Dierauf, T. A.; Marler, R. L. 1971. Effect of exposure, clay treatment, and storage on survival and growth of loblolly pine seedlings. Occas. Rep. 34. Virginia Division of Forestry: 1-10.

Echols, R. J.; Ezell, A. W.; Meier, C. E.; McKinley, C. R. 1990. Dry site survival of bareroot and container seedlings of southern pines from different genetic sources given root dip and ectomycorrhizal treatments. Tree Planters' Notes. 41(2): 13-21.

Johnson, M. S. 1984. The effects of gel-forming polyacrylamides on moisture storage in sandy soils. Journal of the Sciences of Food and Agriculture. 35: 1196-1200.

Kroll, James C.; Deauman, William C.; Foster, C. Darwin; Kulhavey, David L.; Tracey, David. 1985. Survival of pines on droughty soils: two year results. In: Proceedings: southern silvicultural research conference; 1984 November 7-8; Atlanta, GA. Atlanta, GA: U.S. Department of Agriculture, Forest Service, Southern Region: 128-130.

Magnussen, Steen. 1986. Effects of root-coating with the polymer waterlock on survival and growth of drought-stressed bareroot seedlings of white spruce (Picea glauca (Moench) Voss) and red pine (Pinus resinosa Ait.). Tree Planters' Notes. 37(1): 15-17.

Mullin, R. E.; Bunting, W. R. 1979. Another look at clay dipping of bare-root nursery stock. Forestry Chronicle. 55(5): 183-188.

Mullin, R. E.; Hutchison, R. E. 1977. Agricol, clay and water dipping tests with jack pine and black spruce nursery stock. Forest Research Notes. 10: 1-3.

Owston, Peyton W.; Stein, William I. 1972. Coating materials protect Douglas-fir and noble-fir seedlings against drying conditions. Tree Planters' Notes. 23(3): 21-23. 
Ryker, Russell. 1981. Tree seedling root-dip trials. Paper presented at the Intermountain Region Silviculture Workshop; 1981 November 16-18; Pocatello, ID. Ogden, UT: U.S. Department of Agriculture, Forest Service, Intermountain Region. 5 p.

Sloan, John P. [In press]. The use of root dips on North American conifer seedlings: a review of the literature. Tree Planters' Notes.

Steele, Robert; Cooper, Stephen V.; Ondov, David M.; Roberts, David W.; Pfister, Robert D. 1983. Forest habitat types of eastern Idaho-western Wyoming. Gen. Tech. Rep. INT-144. Ogden, UT: U.S. Department of Agriculture, Forest Service, Intermountain Research Station. 122 p.

Steele, Robert; Pfister, Robert D.; Ryker, Russell A.; Kittams, Jay A. 1981. Forest habitat types of central Idaho. Gen. Tech. Rep. INT-114. Ogden, UT:
U.S. Department of Agriculture, Forest Service, Intermountain Research Station. 138 p.

Tabor, C. A.; Davey, C. B. 1966. Clay-suspension root coating as antidesiccants and rhizospheric nutrient sources. In: Soil Science Society of America Proceedings. 30: 516-520.

Tung, Chao-Hsiung; Batdorff, Jim; DeYoe, David R. 1986. Survival and growth of Douglas-fir seedlings with spot-spraying, mulching, and root-dipping. Western Journal of Applied Forestry. 1(4): 108-111.

Tuskan, A. Gerald; Ellis, Patricia A. 1991. Auxinimpregnated hygroscopic gel: effects on ponderosa pine and common hackberry seedlings. New Forests. 5(4): 359-367.

Williston, Hamlin L. 1967. Clay slurry root dip impairs survival of loblolly pine seedlings in Mississippi. Tree Planters' Notes. 18(4): 28-30. 
Sloan, John P. 1994. Root dipping of conifer seedlings shows little benefit in the Northern Rocky Mountains. Res. Pap. INT-RP-476. Ogden, UT: U.S. Department of Agriculture, Forest Service, Intermountain Research Station. 12 p.

In the growth chamber, in the greenhouse, and in field studies, root dipping of bareroot lodgepole pine, ponderosa pine, Douglas-fir, and Engelmann spruce seedlings did not improve seedling survival, shoot growth, or root growth under dry soil conditions. Seedling root growth varied with tree species, soil type, and type of root dip.

Keywords: root growth, tree planting, hydrophilic gel, vermiculite, slurry, conifers 


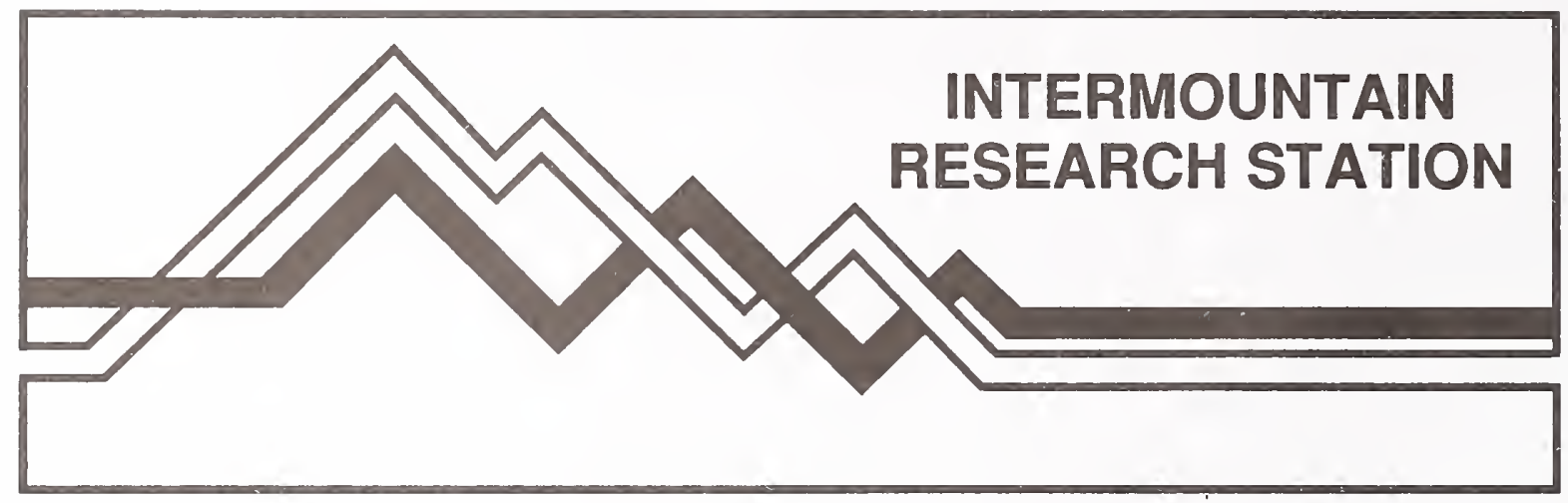

The Intermountain Research Station provides scientific knowledge and technology to improve management, protection, and use of the forests and rangelands of the Intermountain West. Research is designed to meet the needs of National Forest managers, Federal and State agencies, industry, academic institutions, public and private organizations, and individuals. Results of research are made available through publications, symposia, workshops, training sessions, and personal contacts.

The Intermountain Research Station territory includes Montana, Idaho, Utah, Nevada, and western Wyoming. Eighty-five percent of the lands in the Station area, about 231 million acres, are classified as forest or rangeland. They include grasslands, deserts, shrublands, alpine areas, and forests. They provide fiber for forest industries, minerals and fossil fuels for energy and industrial development, water for domestic and industrial consumption, forage for livestock and wildlife, and recreation opportunities for millions of visitors.

Several Station units conduct research in additional western States, or have missions that are national or international in scope.

Station laboratories are located in:

Boise, Idaho

Bozeman, Montana (in cooperation with Montana State University)

Logan, Utah (in cooperation with Utah State University)

Missoula, Montana (in cooperation with the University of Montana)

Moscow, Idaho (in cooperation with the University of Idaho)

Ogden, Utah

Provo, Utah (in cooperation with Brigham Young University)

Reno, Nevada (in cooperation with the University of Nevada)

The policy of the United States Department of Agriculture Forest Service prohibits discrimination on the basis of race, color, national origin, age, religion, sex, or disability, familial status, or political affiliation. Persons believing they have been discriminated against in any Forest Service related activity should write to: Chief, Forest Service, USDA, P.O. Box 96090, Washington, DC 20090-6090. 